$1,2,3,4,5,6,7$ Sağlık Bilimleri niversitesi Ümraniye Eğitim ve Araştırma Hastanesi, İstanbul,

Türkiye

1e-posta:

habibsevimli@gmail.com ORCID: 0000-0003-4475-1669

e-posta: drhayrullahy@gmail.com ORCID: 0000-0001-8057-540X

${ }^{3}$ e-posta:

ggokselinbeleli@gmail.com ORCID: 0000-0001-5974-8695

${ }^{4}$ e-posta: drhaticeseyma_@hotmail.com ORCID: 0000-0003-2823-9577

5 e-posta:

dr.serdar55@hotmail.com ORCID: 0000-0002-6186-6110

${ }^{6}$ e-posta: dralgin@hotmail.com ORCID: 0000-0002-9016-9701

e-posta:

drseroglu@gmail.com ORCID: 0000-0002-3183-3713

Atıf için: Hatice Şeyma AKÇA, Habib SEVIMLi, Hayrullah YÖNAK, Gökselin BELELi, Serdar

ÖZDEMIR, Abdullah ALGIN, Serkan Emre EROĞLU, Ölümün

De Rengi Var, Bu Sefer Mor;

Metanol, Balıkesir Medical Journal, 2020;4(2): 29-33

Başvuru Tarihi: 03.05.2020 Kabul Tarihi: 16.06.2020 Yayınlanma Tarihi: 23.06.2020

Sorumlu Yazar: Hatice Şeyma AKÇA, Sağıık Bilimleri Üniversitesi Ümraniye Eğitim ve Araştırma Hastanesi, İstanbul, Türkiye e-posta: drhaticeseyma_@hotmail.com

\section{Ölümün De Rengi Var, Bu Sefer Mor; Metanol}

\author{
Death Also Have Color, This Time Purple; Methanol
}

\begin{abstract}
Habib SEVIMLi ${ }^{1}$, Hayrullah YÖNAK ${ }^{2}$, Gökselin BELELi ${ }^{3}$, Hatice Şeyma AKÇA ${ }^{4}$, Serdar ÖZDEMIR ${ }^{5}$, Abdullah ALGIN ${ }^{6}$, Serkan Emre EROĞLU ${ }^{7}$
\end{abstract}

Öz

Giriş: Metanol, metabolitleri tarafından toksik olan ve ahşabın damıtılmasıyla elde edilen renksiz, kokusuz bir alkol türüdür.

Olgu: 64 yaşında kadın hasta, son bir aydır çift görme, denge kaybı ve 2 hafta boyunca beslenme kaybı, başvuru günü ise uyuşukluk ile ilgili soruları cevaplamada güçlük şikayetleri ile acil servisimize başvurdu. Ekstremitelerinde pembe-mor hiperemi vardı ve her iki dizde de yaygın dermatit düşünüldü. Hikâyede diz ağrısı için odun alkolünün topikal olarak uygulandıktan sonra dizlerde dermatit geliştiği öğrenildi ve hastaya metanol zehirlenmesi teşhisi kondu. Bilincin bozulması üzerine entübasyon kararı verildi ve hastanemizin anestezi ve reanimasyon ünitesinde entübe olarak hemodiyaliz yapıldı. Yoğun bakım ünitesine yatışından 3 gün sonra kardiyak arrest gelişti ve hasta ex oldu.

Tartışma: Anyon boşluğu artmış metabolik asidoz vakalarında, nedeni açıklanamayan, metanol toksisitesinin ihmal edilmemesi ve bu durumun ölümcül olabilmesini hatırlatmayı amaçladık.

Anahtar Kelimeler: metanol; metabolik asidozis; dermatit

\section{ABSTRACT}

Introduction: Methanol is a colorless and odorless alcohol type that is toxic by its metabolites and is obtained by distillation of wood.

Case Report: A 64-year-old female patient was admitted to our emergency department with complaints of double vision, difficulty in answering questions and drowsiness. Her extremities had pink-purple hyperemia, suggesting widespread dermatitis in both knees. It was found that dermatitis developed after the patient was applied wrapping from wood alcohol for knee pain, and the patient was diagnosed with methanol poisoning. Upon the disruption of her consciousness, an intubation decision was made and hemodialysis was performed in the anesthesia and reanimation unit of our hospital while the patient was intubated. After 3 days of her hospitalization in the intensive care unit, the patient was exitus with a development of cardiac arrest.

Discussion: We aimed to remind you that in metabolic acidosis cases with increased anion gap, methanol toxicity is a reason that should not be neglected and may be fatal.

Keywords: methanol; metabolic acidosis; dermatitis 


\section{INTRODUCTION}

Methanol is a colorless odorless alcohol type that is toxic by its metabolites and is obtained by distillation of wood. It is used in the chemical industry to obtain products such as cologne, antifreeze, stain removers and spirits (1). Toxicity caused by metabolites; responsible for metabolic acidosis and blindness, vision problems, cardiovascular problems, kidney failure and death. This exposure can be by oral intake, inhalation or transdermal. In our presentation, we will present the clinical picture in which the alcohol used in a local folk treatment is responsible for long-term ( 1 month) dressing and closure of the knee by absorbing cotton. The name of this alcohol in Turkish is "ispirto" meaning spirit. For cleaning and fuel at home used. It is produced by adding methyl alcohol to prevent the use of ethyl alcohol as a drink, and purple color is added to understand that it is dangerous.

With this case report, we aimed to draw attention to the methods of treatment known incorrectly and the consequences.

\section{CASE REPORT}

A 64-year-old female patient was admitted to our emergency department with complaints of double vision for the last past month, loss of balance and loss of nutrition for 2 weeks, difficulty in answering questions on the day of admission and drowsiness. The patient, whose in medical history was only Diabetus Mellitus, did not have any history of drug use, alcohol or cigarette use other than sulfonylurea group medication. Vital signs, blood pressure arterial 144/77 mm/Hg, heart rate 74 beats/min, oxygen saturation in room air $98 \%$, body temperature was measured as $36.7^{\circ} \mathrm{C}$, fingertip blood sugar as $112 \mathrm{mg} / \mathrm{dl}$. Electrocardiography revealed a sinus rhythm with 1:1 AV conduction. Cardiovascular, respiratory and abdominal examinations did not reveal any significant pathological findings during the physical examination. No pathological findings were found on neurological examination and cranial nerve examination, except for horizontal nystagmus. Cranial tomography and diffusion MRI were normal. Her extremities had pink-purple hyperemia, suggesting widespread dermatitis in both knees (Image 1).

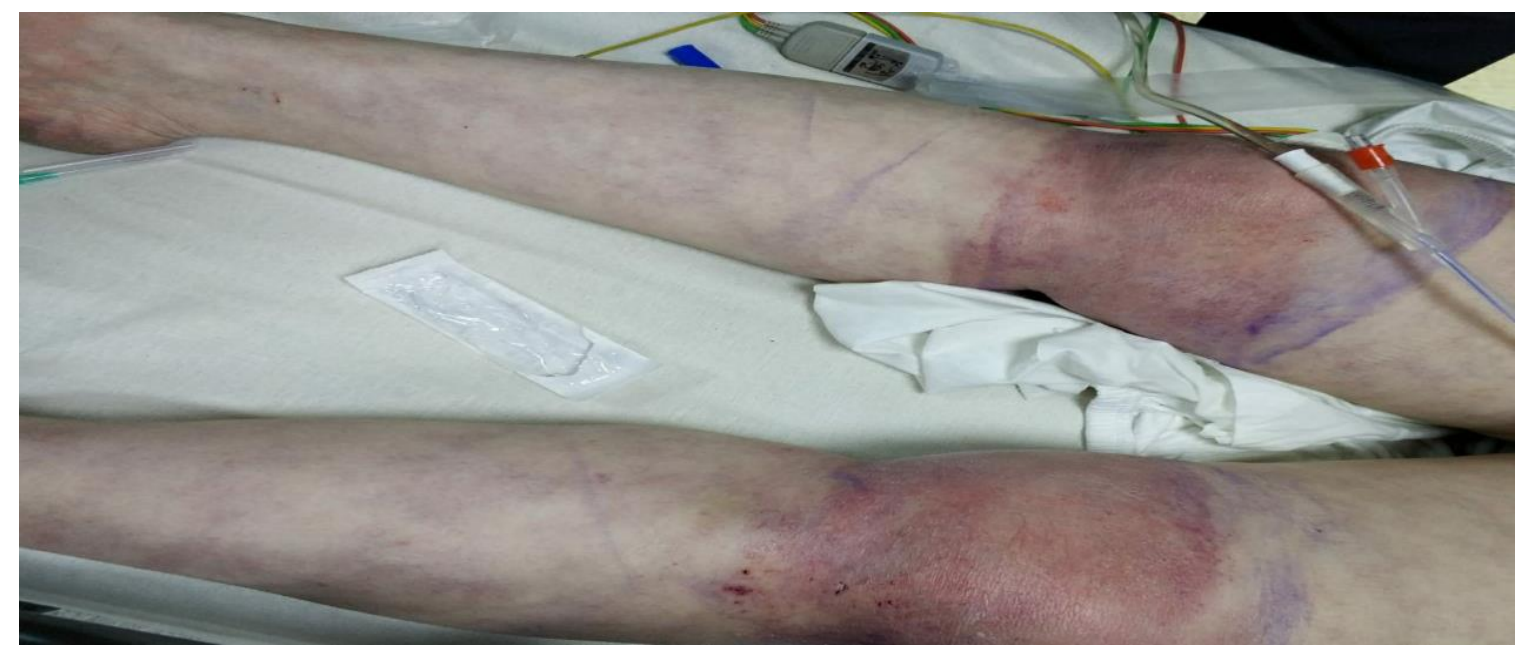

Image 1. Widespread dermatitis in both knees 
In her laboratory evaluation, her blood count, liver and kidney function tests, and electrolytes did not show any impairment. Patient's laboratory WBC:8,070 10 3 /L, Hgb:14,4 g/dL, ALT:21 $\mu / L, A S T: 22 \mu / L$, glucose: $104 \mathrm{mg} / \mathrm{dL}$, creatinine:0.83 mg/dL, potassium:5.1mEq/L, sodium:145 mEq/L, BUN: $23.54 \mathrm{mg} / \mathrm{dL}$, amylase:151 $\mu / \mathrm{L}$, calcium:8.17 mg/dL, ethyl alcohol <10 mg/dL, APTT: $32.9 \mathrm{sec}$, PT: $15.7 \mathrm{sec}$, troponin I:0.001 (cutoff: 0.0262), CRP: $<0.2$ (cutoff: 0.5 ) salicylate: $<5 \mathrm{mg} / \mathrm{dL}$.The patient's first blood gas taken: Ph:7.11, Pco2:27.3 mmhg, HCO3:9,9 mmol/L, BE:-19.3 and lactate:2.2, and anion gap was calculated as 34.1. When anamnesis was taken again to investigate the causes of increased metabolic acidosis in the anion gap, it was found that dermatitis developed in the knees after the patient was applied wrapping from wood alcohol for knee pain, and the patient was diagnosed with methanol poisoning due to transdermal methanol absorption. In the follow-up of the patient, hemodialysis was planned in our hospital, but upon disruption of consciousness, an intubation decision was made and hemodialysis was performed as intubated in the anesthesia and reanimation unit of our hospital. During the follow-up in the intensive care unit, the patient, who was ventilated with the support of MV in SIMV-PC mode, was hemofiltrated two more times. Despite the initiation of dual inotropic treatment, the patient who developed low blood pressure on the 3rd day of the intensive care follow-up of the patient with diuresis, and sudden cardiac arrest developed and exitus was accepted as no response to the effective resuscitation performed for 45 minutes.

\section{DISCUSSION}

Methanol is a kind of alcohol used in making various paint and stain removers, car glass washing liquids, antifreeze, cologne and spirits. It usually enters the organism through oral intake (false alcohol or suicidal interventions), rarely by inhalation, and very rarely through the skin and placenta (2). Methanol itself is non-toxic. Metabolites of methanol such as formaldehyde and formic acid are responsible for the clinical picture. Symptoms that can be seen due to exposure; if oral intake can be nausea, vomiting, abdominal pain. If there is skin exposure, lesions, vision problems, and consciousness disorders may be observed in that area. Classically, visual problems resulting from retinotoxicity caused by formaldehyde disruption of retinal oxidative phosphorylation occur in $37-72 \%$ of patients and are reversible in $11-18 \%$ (3-5). The degree of encephalopathy is different. It can be traced on a wide scale ranging from the feeling of walking in the air to coma (6). The formic acidosis metabolite is responsible for metabolic acidosis, and metabolic acidosis with high anion aperture is observed, which is the most remarkable picture in the laboratory. As the level of methanol in the blood increases, an increase in serum osmolarity is observed. The greater the amount of exposure or exposure time, the deeper and more severe acidosis and developing anion gap. In addition, the severity of encephalopathy and visual impairment and the depth of metabolic acidosis show serious parallels. In addition, bradycardia, myocardial depression and hypotension are among the signs that metabolic acidosis is severe. In studies conducted in our country, the dose limit of methyl alcohol causing death was found to be $50-755 \mathrm{mg} / \mathrm{dl}$. In one study, $10.7 \%$ of the victims were found to be drinking cologne as a source of methanol, $50 \%$ had brain edema and hyperemia, but putaminal necrosis was not observed, and only $1.7 \%$ had intracranial bleeding (7). The first clinical experience with the introduction of the skin through the use of fluids containing methanol during dermal cleaning before catheter placement in infants and the use of compounds containing methanol in 
the treatment of superficial dermal diseases and other studies have confirmed that transdermal methanol exposure may develop (8). Although reports of transdermal methanol exposure are quite rare in the literature, four cases in total have been reported in our country. Soysal et al. presented a case of intoxication developing after massaging the head with a liquid containing methanol (9). In our case, an application was applied to the knee region in order to relieve pain. The treatment has four modalities; immediate cessation of exposure, inhibition of conversion to metabolites, removal of metabolites and bicarbonate therapy. Oral or dermal, exposure should be stopped immediately. If there is oral intake and less than an hour has passed, gastric lavage should be applied. If there is transdermal exposure, the exposed area should be washed with water. Activated charcoal has no place in treatment since methanol and activated carbon are not well bonded. As an antidote, ethanol or fomepizole is administered to inhibit alcohol dehydrogenase to prevent conversion to metabolites. Indications are methanol exposure, plasma methanol concentration $>20 \mathrm{mg} / \mathrm{dL}$, osmolal gap $>10 \mathrm{mosm} / \mathrm{L}$, and signs of metabolic acidosis $(10,11)$. Ethanol can be given first with the help of oral, intravenous (IV) or nasogastric tubes. It should be remembered that level monitoring is required for ethanol and can lead to confusion. On the other hand, bicarbonate, folic acid and thiamine are also included in the treatment components, as they will speed up the conversion of formic acid to water and carbon dioxide. Since folate helps as a cofactor in the breakdown of formic acid, $50 \mathrm{mg}$ IV should be given every 4 hours for several days. Hemodialysis is indicated if there are visual problems, signs of central nervous system dysfunction, peak methanol level>25 mg / dL, severe metabolic acidosis, or a history of intake of more than $30 \mathrm{ml}$ (12). Although blood methanol level was not measured in our hospital, our patient was directly hemodialyzed after intubation due to visual problems, accompanied by central confusion, deep metabolic acidosis, and transdermal marurism, and intravenous ethanol treatment was applied. Methanol can cause a fatal intoxication that develops due to its easy accessibility in our country, its illegal production of illegal alcoholic beverages, or the use of people for pain relief in local treatments, as in this case.

With this report, we aimed to remind that in metabolic acidosis cases with an increased anion gap, the cause of which cannot be explained, it is an etiology that should not be kept in mind since methanol toxicity is rare but fatal. In addition, as a current subject, we aimed to state that caution should be exercised in relation to the COVID-19 pandemic due to the increased use of hand disinfectants, alcohol, cologne in society.

\section{REFERENCES}

1. Gok E, Horoz M, Turgutalp M, Kıykım AA. Fatal Transdermal Methanol Intoxication: A Case Report and Review of Literature. Turkiye Klinikleri J Med Sci. 2011;31(1):234-9

2. Koprulu AS, Sener T, Sungar D, Turunc V, Kalfaoglu E. Accidental Transdermal Methanol Poisoning: Diffificulties and Suggestions in Therapy Case Report. Turkiye Klinikleri J Case Rep. 2016;24(1):89-92

3. Chu J, Wang RY, Hill NS. Update in clinical toxicology. Am J Respir Crit Care Med. 2002;166(1):9-15.

4. Paasma R, Hovda KE, Tikkerberi A, Jacobsen D. Methanol mass poisoning in Estonia: outbreak in 154 patients. Clin Toxicol (Phila) 2007;45(2):152-7

5. Benton CD Jr, Calhoun EP Jr. The ocular effects of methyl alcohol poisoning; report of a catastrophe involving 320 persons. Am J Ophthalmol 1953;36(12):1677-85. 
6. Karaduman F, Asil T, Balci K, Temizoz O, Unlu E, Yilmaz A, et al. Bilateral basal ganglioniclesions due to transdermal methanol intoxication. J Clin Neurosci 2009;16(11): 1504-6.

7. Yayci N, Ağritmiş H, Turla A, Koç S. Fatalities due to methyl alcohol intoxication in Turkey:an 8-year study. Forensic Sci Int 2003;131(1): 36-41.

8. Batterman SA, Franzblau A. Time-resolved cutaneous absorption and permeation rates ofmethanol in human volunteers. Int Arch Occup Environ Health 1997;70(5):341-51.

9. Soysal D, Yersal Kabayegit O, Yilmaz S, Tatar E, Ozatli T, Yildiz B, et al. Transdermal methanol intoxication: a case report. Acta Anaesthesiol Scand 2007;51(6):779-80.

10. Barceloux DG, Bond GR, Krenzelok EP, Cooper H, Vale JA; American Academy of Clinical Toxicology Ad Hoc Committee on the Treatment Guidelines for Methanol Poisoning. American Academy of Clinical Toxicology practice guidelines on the treatment of methanol poisoning. J Toxicol Clin Toxicol 2002;40(4):415-46.

11. Mégarbane B, Borron SW, Baud FJ. Current recommendations for treatment of severe toxic alcohol poisonings. Intensive Care Med 2005;31(2):189-95.

12. Hovda KE, Froyshov S, Gudmundsdottir H, Rudberg N, Jacobsen D. Fomepizole may change indication for hemodialysis in methanol poisoning: prospective study in seven cases. Clin Nephrol 2005;64(3):190-7. 